\title{
PROBLEMS OF BANKING LEGAL RELATIONSHIPS
}

\author{
Stanislav Ivanov', Yuliia Hromenko ${ }^{2}$, Valeriia Rodina ${ }^{3}$
}

\begin{abstract}
In modern conditions of management, the aspects of ensuring the stability of banks and the development of the banking system of Ukraine are of particular importance. During 2014-2017 in our country, 88 banks were recognized as insolvent, almost all of them - commercial. This tendency is disappointing. Most scholars assert that the turnaround of the banking system is possible only through the improvement of deposit, credit, and settlement operations. This statement is undoubtedly true, but these scholars forget about the importance of regulating the legal relationships that arise in the banking sector and establishing the interaction between the entities of such legal relationships. The purpose of the research is to determine the essence of banking legal relationships in Ukraine based on the existing scientific approaches, the current legislation of Ukraine and the practice of its implementation, as well as the specific and problematic aspects of harmonizing the interests of the entities of the relevant legal relations. For this purpose, the essence and structure of banking legal relationships are considered. It is determined that the main structural elements of these legal relationships are: 1) objects, 2) the content of banking legal relationships, 3) the basis of banking legal relationships - legal norms and legal facts, 4) entities (participants) the direct participants in banking relationships, the bearers of mutual rights and obligations. The conclusions of the article state that Ukrainian banking legislation requires a serious revision concerning the coordination of the interests of the entities of banking legal relationships. The key task is to eliminate unnecessary and outdated normative and legal acts that could cause legal confusion or impose excessive burdens on entities of banking legal relationships. In developing the modern regulatory framework for the interaction of entities of banking relationships, a new rapid spread of cyber-risks, compliance risks and financial crime risks, which significantly affects the state of the banking system and is not reflected in the current banking legislation of Ukraine, should be taken into consideration. Banks as the main entities of banking relationships should assume risks and financial responsibility. It will contribute to the stabilization of the banking system of Ukraine and the economic development of the national economy.
\end{abstract}

Key words: bank, banking service, entity, legal relationships, banking system, interests.

JEL Classification: G21, K30

\section{Introduction}

Today, Ukraine faces an important task, which is to ensure the active development of the economy, to strengthen the democratic principles of our state, and to raise the living standards of the population. It is impossible to achieve this without the effective functioning of the credit and financial mechanism, the component of which is the banking system. The banking system is a connecting link between the subjects of microeconomics and macroeconomic processes and it substantially affects the success or failure of any economic reforms in our country. Unfortunately, nowadays the statistics affirm that the banking system of Ukraine is not in the best state. Thus, according to the data of the National Bank of Ukraine (NBU), since the beginning of 2017 , financial institutions have closed $26 \%$ of their subsidiary offices. A part of the branches was closed due to the insolvency of banks. For the period of 2014-2017, the NBU declared 88 banks insolvent, and 27 of them were withdrawn from the market. Other banks spare: reduce old offices in order to open offices of a new type or invest in the development of remote service channels. Deposit, credit, and settlement operations play a key role in the activities of banks. However, it is also important how each separate bank will build legal relationships with other entities of the banking system.

That is why every year the necessity of solving theoretical and practical problems concerning the enforcement of optimal relations between the interested parties of banking legal relationships is

\footnotetext{
Corresponding author:

${ }^{1}$ Kharkiv National University of Internal Affairs, Ukraine.

E-mail: stanislavivanov713@gmail.com

${ }^{2}$ Donetsk Law Institute of the Ministry of Internal Affairs of Ukraine, Ukraine.

E-mail: gromenko.u@gmail.com

${ }^{3}$ Donetsk Law Institute of the Ministry of Internal Affairs of Ukraine, Ukraine.

E-mail: rodinavaleriaviktorovna@gmail.com
} 
becoming increasingly important, but the system approach to solving these problems has not yet been formed. Intensification of globalization and integration processes in the global economy requires the banking system of Ukraine to enter the international markets. Ukraine should become a full member of the international banking system. According to the Law of Ukraine "On Banks and Banking", the banking system of Ukraine consists of the National Bank of Ukraine and other banks, as well as branches of foreign banks, which have been established and operate in the territory of Ukraine in compliance with the present Law provisions and other laws of Ukraine. A bank is a legal entity that has an exclusive right, under the NBU license, to render the banking services and is included in the State Register of Banks. Due to the existence of banks, there is a constant circulation and accumulation of capital. Banks are in a state of constant search and struggle in new and upgraded segments of the markets, as well as the entities of the real economy sector. Globalization and intensification of the competition stimulate banks to in-depth study of the banking segment of the financial market of the country; understanding and taking into account the requests of existing and potential clients, the needs of their business; development and introduction of new financial services and their promotion on the market; the use of elastic and differentiated pricing methods; formation and strengthening of the client base (Vasylieva, 2014). The banking system of Ukraine has a permanent evolutionary development, which also confirms the relevance of scientific research.

A set of interrelated and complementary general scientific and special methods aimed at obtaining objective results was used to realize a goal of the research process. Thus, the method of historical and logical analysis of literary sources was applied to study the level of problem development in the domestic and foreign scientific literature. Method of functional and structural analysis involves the study of state regulation of entities relations. The statistical method is used for the analysis of facts and phenomena, their synthesis for research. System and complex methods ensured the integrity of the study. The method of generalization was used to formulate conclusions, recommendations of ways to improve the relevant legal relationships.

\section{Scientific approaches to the problem of banking legal relationships}

The problem of banking legal relationships is not new; a number of foreign and domestic scholars paid attention to it in their scientific works. V. Nahrebelnyi (2010), investigating the public and legal principles of regulation of the banking system, stated that the characteristic feature of the legal relationships formed in the banking system is their mediation of relations concerning the permanent or perpetual movement of foreign funds between their members, based on a certain level of trust between them. The higher the level of trust between the participants of these relations, the more stable and dynamic the financial and economic relationships, and as a result, this will benefit the country's economic system as a whole. A. Slavko (2016), studying the peculiarities of regulation of banking relationships under the conditions of the regime of the occupied territory and the regime of the anti-terrorist operation, noted that the public and legal regulation of banking relations in the occupied territories and zone of ATO actually reduces to the prohibition of the activities of banking institutions and to the termination of the implementation of any financial operations until the possibility of restoring the NBU's ability to conduct banking supervision. Another scientist M. Kuntsevych (2016) devoted his scientific research to clarify the features of the subjective composition of banking relationships related to banking secrecy. S. Kurovskyi (2014) considered the features of banking relationships as an object of financial and legal regulation, determining the features of these legal relations and their characteristics. In addition, the author analysed the peculiarities of the objective regulation of banking law and banking legislation. D. Hetmantsev and N. Shuklina (2007) devoted their textbook "Banking Law of Ukraine" to a separate issue to clarify the essence of the concept of "banking relationships". In addition, scientists gave a rather exhaustive list of peculiarities of banking legal relationships, which many other scholars used as a basis for their studies. V. Vashchenko in the textbook "Banking Law" (2006) allocated a separate chapter, in which he considered the concept, composition, types, and features of banking legal relationships. The author emphasized that banking relationships can be administrative, financial, civil or economic by their legal nature. Taking into account the heterogeneity of banking relationships, V. Vashchenko distinguished both common and distinctive features of banking relationships. A. Kovalenko (2016), considering the public and legal regulation of banking activity in Ukraine in the context of European integration, devoted a separate unit to clarify the essence of the concept of "banking relationships". The scholar stressed the need to distinguish between public and private relations in the field of banking, based on the public functions of the bank. In addition, the author determined the entities of banking relationships and provided a detailed description of their activities. The question of subjects of law and entities of legal relations was considered in the general theory of law and the theory of administrative law in the works of S. Alekseiev (1982), R. Khalfina (1974) and Ts. Yampolskaya (1958). In the scientific article, T. Chernadchuk (2013) considered the theoretical issues of determining the entity of information and banking legal relationships. The scientist concluded that the entities of information banking legal relationships 
are individualized or specific subjects of information law, which realize their legal personality in legal relationships, acting as "implementers" of information objective rights and obligations in the banking sector.

Thus, banking relationships were the subject of scientific researches, in which scholars considered this problem in different ways. However, the analysis of their works proves that almost no attention was paid to the problems of determining the legal mechanisms for the coordination of the interests of the entities of banking legal relationships, as well as the protection of their financial interests.

\section{Banking services}

Today, the Ukrainian government is actively reforming the banking activities. The principles, methods, and instruments of banking relations are changing, as well as the regulatory framework is being improved. The subject of banking law is the social relations arising in the banking activities, in particular, relations that govern the process of building, functioning, and development of both the banking system and a separate bank, the implementation of banking services by banks, the regulation of the banking system by state bodies in the interests of citizens, organizations and the state, etc. (Kostiuchenko, 2003).

Banks in Ukraine are entitled to engage in banking activities based on a banking license by means of rendering banking services. Most scholars believe that banking operations or services consist of satisfying the needs of individuals and legal entities in bank servicing. In accordance with the current legislation, only banks are entitled to render banking services. The banking services market acts as the foundation for Ukraine's economic development.

According to O. Vovchak (2008), banking services are actions of the bank aimed at increasing its profitability, or various types of banking activities that accompany and optimize banking transactions. The banking service can be regarded as the transfer of banking information. The peculiarities of banking services are:

1 ) as a rule, additional resources are not required for rendering services to banks;

2) banks receive the largest part of the income from rendering services in the form of a commission;

3) within rendering services, the activities of banks aimed at committing legal and actual actions, which are not directly related to the financial consequences.

In accordance with the Law of Ukraine No. 2121III "On Banks and Banking" as of December 7, 2000, banking services include:

1) accepting deposits in currency and investment metals from an unlimited number of legal entities and individuals;

2) opening and maintaining customers' current (correspondent) accounts, including those in investment metals, and escrow accounts;
3) placing the currency and investment metals accepted as deposits (including the balances on the current accounts) on the bank's own behalf and for its own account.

In addition to rendering the financial services, any bank is entitled to be engaged in the activities related to: investments; issue of its own securities; lottery tickets issue and distribution, holding lottery draws; custody of valuables and leasing of individual bank safes; cash collection and cash in transit services; maintenance of registers of registered securities holders (except own shares); consulting and information services with regard to the banking and other financial services. A bank may render banking and other financial services in domestic currency and, subject to a separate license from the $\mathrm{NBU}$, in a foreign currency.

\section{The structure of banking relationships}

In the process of meeting the need for banking services, economic entities enter into certain economic and legal relations with banks. Yu. Vashchenko (2006) considers banking relationships as relations regulated by the law in the field of banking, namely in the process of managing the banking system, implementing such operations as accepting deposits from legal entities and individuals, opening and maintaining current accounts of customers and correspondent banks, including the transfer of funds from these accounts using payment instruments and passing them into accounts, placing borrowed funds on their own behalf, on their own terms, and at their own risk, as well as performing other operations on the basis of a license issued by the National Bank of Ukraine or a separate permit.

The structure of banking relationships consists of the following elements:

- objects - banking activity and relations arising in the course of rendering banking services (property (money, securities and metals), non-property (bank secrecy and reputation) and organizational (corporate responsibility, internal structure, banking supervision));

- the content of banking legal relationships implementation of subjective legal rights and fulfilment of legal obligations;

- the basis of banking legal relationships - legal norms and legal facts;

- entities (participants) of banking relationships the state, legal entities, and natural persons.

The entities of banking relationships are the direct participants in banking relationships; they are the bearers of mutual rights and obligations. They must actively interact with each other in order to exercise their rights and obligations fully, and the state must create all the necessary conditions for the implementation of such interaction, in which the interests of any participant will not be violated. In the process of interaction between the entities of banking legal relationships (Figure 1), they are guided by the Constitution of Ukraine, 


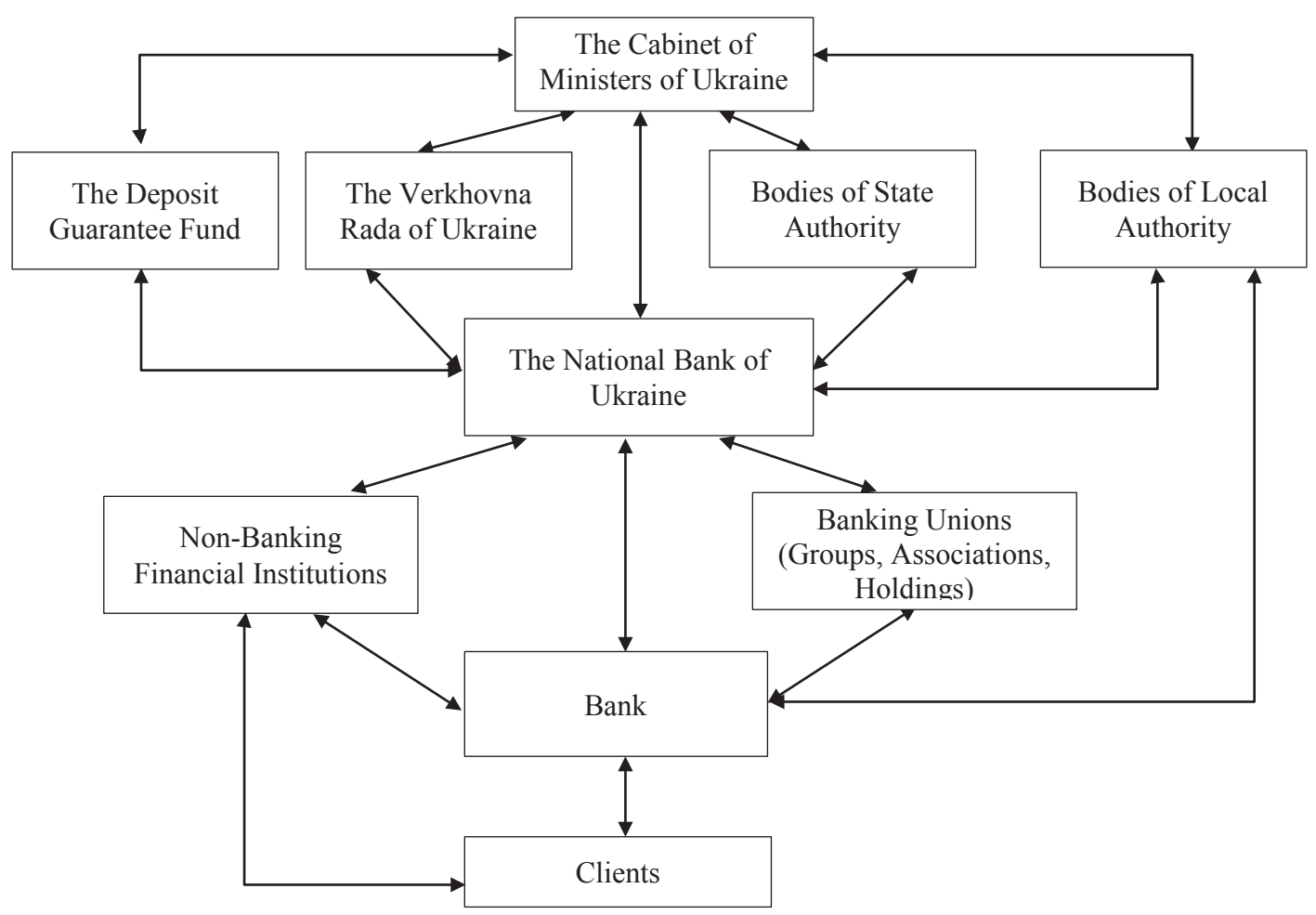

Figure 1. Interconnection of entities of banking legal relationships in Ukraine

decrees of the President of Ukraine, resolutions of the Verkhovna Rada of Ukraine, general laws; special laws; normative acts of the National Bank of Ukraine; internal organizational standards; international legal acts.

Experts point out that reforms harmonizing the interests of the entities of banking legal relationships as to de-offshorization are still being slowed down. Thus, within the framework of the rules of transfer pricing (the Law of Ukraine No. 408-VII as of July 04, 2013) the concept of "controlled operation" is introduced, as well as a list of "low tax" specializations, with which transactions are recognized as controlled. However, today there is no practice of applying these rules, and they are quite easy to avoid. The duty to disclose the ownership structure and the final beneficiary (the Law of Ukraine No. 1701-VII as of October 14, 2014) also has weaknesses. The head of a company must provide the state registrar with information about the ultimate beneficial owner (controller) of the company, including the ultimate beneficiary of its founder (if the founder is a legal entity). He is also obliged to provide information about the ownership structure of founders - legal entities, which allows identifying individuals as owners of substantial participation in these legal entities. Failure to provide such information entails imposing an administrative fine of up to $8,500 \mathrm{UAH}$ on the manager. However, this is not such a large pay for business security. Moreover, the provision of inaccurate or incomplete information does not involve liability, which makes these requirements declarative (Busol, 2017).
Meanwhile, a new capital order is being created in the world. The domestic banking system should implement modern fundamental initiatives for the reform of some aspects of Basel III, which are developing into the socalled capital regime of Basel IV. The above changes are numerous and affect a wide range of capital calculations for banks. At the same time, it simplifies and complicates the banking system, as well as provides an additional level of conservative capital. Increasing the size of conservative capital will facilitate the process of reconciling the interests of the entities of banking legal relationships. New standards and proposals are aimed at ensuring that banks have capital that is appropriate for their risks.

\section{Risks in banking activities}

Many risks affect the interaction of entities of banking legal relationships and the coordination of interests between them in a negative way. Compliance risks are the risks of legal penalties, financial losses or loss of reputation due to failure to comply with legislative acts, market standards, as well as standards and internal documents of the bank, including procedures. Risks in banking activities stem from the specifics of banking services that are carried out in a market environment and mean the probability of receiving less income than expected, lowering the value of assets. Increased banking risks lead to significant losses and, as a consequence, bankruptcy of banks. Entities of banking relationships are interested in reducing the riskiness of banking activities. 
Taking into account the principle of independence of entities of banking relationships for the assessment of strategic risk (Methodological guidelines for the inspection of banks "Risk Assessment System" No. 104 as of March 15, 2004), the Department of Banking Regulation and Supervision must take into consideration the following factors:

- mission, goals, corporate culture and values, risk tolerance;

- management practice to bring to the implementation and modification of strategic plans;

- the state of implementation of strategic plans, frequency and magnitude of changes in a bank attitude towards risk (risk tolerance);

- available information systems of management and supervision means for monitoring business decisions;

- impact of the bank strategic positioning on the public image and good name of the bank regarding its technologies, products, and competitors;

- plans and possibilities for the bank structural reorganization (for example, merger or accession);

- compatibility of strategic initiatives with existing or planned resources;

- bank market position, including market penetration at the geographical and product level;

- bank diversification concerning products, geography and clientele;

- results of the bank plans to introduce new products or services.

According to the Law of Ukraine "On the System of Guaranteeing Deposits of Natural Persons" and the Decree of the President of Ukraine
No. 996/98 “On Measures for Protection of Rights of Natural Persons - Depositors of Commercial Banks of Ukraine" as of September 10, 1998, the National Bank of Ukraine and the Cabinet of Ministers of Ukraine elaborated and approved "Principles of functioning of the Fund for Guaranteeing Deposits of Natural Persons, the procedure for compensating deposits to the depositors of banks" to provide the interests of clients (natural persons) as entities of banking legal relationships. The Fund was created with the purpose of protecting the interests of natural persons-depositors of commercial banks, creating financial possibilities for reimbursing them in case of impossibility of banks to fulfil the requirements of depositors for the return of funds. However, in Ukraine, the applicable legal and regulatory basis for guaranteeing the return of deposits of legal entities has not yet been formed.

\section{Conclusions and practical recommendations}

In Article 58 "Economic Ratios" of the Law of Ukraine "On the National Bank of Ukraine", we propose to establish new indicators of banking activity, that is, the standard of compliance control, indicators of clients' rights protection. In the current banking legislation (the Law of Ukraine No. 2121 "On Banks and Banking" as of December 7,2000), we propose to introduce ratios of Basel IV on banking supervision. Banks as the main entities of banking relationships should assume risks and financial responsibility. It will contribute to the stabilization of the banking system of Ukraine and the economic development of the national economy.

\section{References:}

Alekseev, S. S. (1982). Obshchaya teoriya prava: v2-kh t. T. 2 [The general theory of law: in two vol. Vol. 2]. Moscow: Yurid. lit. (in Russian)

Buso, O. (2017). Political games, abo Stvorennia Derzhavnoho biuro rozsliduvan v Ukraini: monohrafiia [Political games, or Creation of the State Investigation Bureau in Ukraine: monograph]. Kyiv: Sammit-Knyha. (in Ukrainian) Chernadchuk, T. O. (2013). Deiaki pytannia shchodo vyznachennia poniattia "subiekt informatsiinykh bankivskykh pravovidnosyn" [Some questions regarding the definition of "the entity of information banking legal relationships" . Law and Public Administration, 1, 88-91.

Hetmantsev, D. O., Shuklina, N. H. (2007). Bankivske pravo Ukrainy [Banking Law of Ukraine]. Kyiv: Tsentr uchbovoi literatury. (in Ukrainian)

Instruktsiiu pro poriadok rehuliuvannia diialnosti bankiv v Ukraini: Postanova NBU \# 368 (2001, August 28). [Instruction on the procedure for regulating the activities of banks in Ukraine: Resolution of the NBU No. 368 of August 28, 2001]. Baza dannykh Zakonodavstvo Ukrainy, NBU. Retrieved from: http://zakon3.rada.gov.ua/laws/ show/z0841-01\#n25

Khalfina, R. O. (1974). Obshchee uchenie o pravootnoshenii [The general doctrine of law making]. Moscow: Yurid. lit. (in Russian)

Kostiuchenko, O. A. (2003). Pravovi aspekty bankivskoi diialnostiy: posibnyk z problem bankivskoho prava [Legal aspects of banking activity: a manual on banking law]. Kyiv: Krynytsia. (in Ukrainian)

Kovalenko, A. A. (2016). Publichno-pravove rehuliuvannia bankivskoi diialnosti $v$ Ukraini v umovakh yevrointehratsii [Public and legal regulation of banking activity in Ukraine in the conditions of European integration]: author's abstract. dis. ... Candidate of Juridical Sciences: 12.00.07. Kyiv: Open International University of Human Development "Ukraine".

Kuntsevych, M. P., Tarasiuk, H. Yu. (2016). Subiektnyi sklad bankivskykh pravovidnosyn, poviazanykh iz bankivskoiu taiemnytseiu [The subjective composition of banking relationships related to banking secrecy]. Comparative and Analytical Law, 6, 104-106. 
Kurovskyi, S. (2014). Bankivski vidnosyny yak obiekt finansovo-pravovoho rehuliuvannia [Banking relationships as an object of financial and legal regulation]. Theory and practice of intellectual property, 6, 152-159.

Memorandum vzaiemorozuminnia mizh Uriadom Ukrainy i Orhanizatsiieiu ekonomichnoho spivrobitnytstva ta rozvytku shchodo pohlyblennia spivrobitnytstva (2014, July 10). [Memorandum of Understanding between the Government of Ukraine and the Organization for Economic Cooperation and Development on deepening cooperation of July 10, 2014]. Baza dannykh Zakonodavstvo Ukrainy, Kabinet Ministriv Ukrainy. Retrieved from: http://zakon2.rada.gov.ua/laws/show/966_003

Metodychni vkazivky z inspektuvannia bankiv «Systema otsinky ryzykiv» \#104 (2004, March 15). [Methodological guidelines for the inspection of banks "Risk Assessment System" No. 104 of March 15, 2004] Baza dannykh Zakonodavstvo Ukrainy, NBU. Retrieved from: http://zakon2.rada.gov.ua/laws/show/v0104500-04

Nahrebelnyi, V. P. (2010). Publichno-pravovi zasady rehuliuvannia vidnosyn v bankivskii systemi Ukrainy [Public and legal principles of regulation of relations in the banking system of Ukraine]. Pravova derzhava: Shchorichnyk naukovykh prats, 2, 197-206.

Pro banky ta bankivsku diialnist: Zakon Ukrainy \#2121-III (2000, December 7). On Banks and Banking: the Law of Ukraine No. 2121-III of December 7, 2000]. Baza dannykh Zakonodavstvo Ukrainy, VR Ukrainy. Retrieved from: http://zakon5.rada.gov.ua/laws/show/2121-14

Pro zatverdzhennia Polozhennia pro orhanizatsiiu vnutrishnoho kontroliu v bankakh Ukrainy \# 867 (2014, December 29). [On Approval of the Regulation on the Organization of Internal Control in Banks of Ukraine No. 867 of December 29, 2014]. Baza dannykh Zakonodavstvo Ukrainy, NBU. Retrieved from: http://zakon2.rada.gov.ua/ laws/show/v0867500-14

Slavko, A. (2016). Osoblyvosti rehuliuvannia bankivskykh vidnosyn za umov dii rezhymu okupovanoi terytorii ta rezhymu provedennia antyterorystychnoi operatsii [Features of regulation of banking relations under the conditions of the regime of the occupied territory and the regime of anti-terrorist operations]. Entrepreneurship, economy and law, 3, 110-115.

Vashchenko, Yu. V. (2006). Bankivske pravo: Navch. Posibnyk [Banking Law: Textbook]. Kyiv: Tsentr navchalnoi literatury. (in Ukrainian)

Vasylieva, T.A. (ed.) (2014). Marketynh u banku: navchalnyi posibnyk [Bank Marketing: textbook]. Sumy: DBA "UAS NBU". (in Ukrainian)

Vovchak, O. D., Rushchyshyn, N. M., Andreikiv, T. Ya. (2008). Kredyt i bankivska sprava: pidruchnyk [Credit and Banking: Textbook]. Kyiv: Znannia. (in Ukrainian)

Yampolskaya, Ts. A. (1958). Subekty sovetskogo administrativnogo prava: dis.... doktora yurid. nauk [Entities of Soviet administrative law: diss. ... Doctor of Law]. Moscow. (in Russian) 